\title{
Google Meet as Learning Media for Vocal Techniques During the Covid-19 Pandemic
}

\author{
Inggri Aulia Silviska*, Diah Latifah \\ Universitas Pendidikan Indonesia \\ Bandung, Indonesia \\ *iinggriaulias@gmail.com
}

\begin{abstract}
Nowadays, direct vocal learning practice becomes difficult because the world is facing the Covid-19 pandemic so that the search for alternative uses of learning media is carried out so that learning activities can be carried out. There is a symptom of the inability of students to apply breathing techniques, diction, and articulation when learning vocals. The use of Google Meet application technology as a learning medium is used for the application of breathing techniques, diction, and articulation. To achieve the goal, the research method used is action research in the classroom, assessing the use of the google meet application to improve breathing techniques, diction, and articulation. This application is an online video communication service that can invite up to 30 students. The results showed that the application of the Google Meet application has the ability to display vocal technique material well so that students can sing vocal works with good breathing techniques and articulation diction.
\end{abstract}

Keywords-Covid-19, Google Meet, breathing technique, diction and articulation

\section{INTRODUCTION}

During the Covid-19 pandemic, almost the entire world, including Indonesia, continues to try to carry out activities as usual without neglecting health protocols. The government has made a policy to allow learning and work activities to be carried out at home. This is considered as the best way to reduce the spread of the corona virus. Until now, the accumulation from around the world has had more than 26 million cases. Indonesia has already had more than 500 thousand cases and it seems that the number is still increasing source by official website of Indonesian Task Force for Covid19. As a result, learning and working from home must be prioritized because not meeting face to face is much better than wearing a mask or face shield with the crowd in one room.

At the beginning of the pandemic, the society stopped activities outside their homes to avoid the corona virus. Several countries have implemented a lockdown system. Stay at home is the most basic way to avoid crowding [1], but the virus continues to spread so that people have to find alternatives to continue carrying out activities, work, and learning safely. One of the alternatives is the use and utilization of technology. The rapid development of technology in the current era of globalization has provided many benefits in various aspects The use of technology has become a human need to help with various activities and problems, including work or learning.

Learning technology grows out of educational practice and audio-visual communication gestures. Learning technologies was originally seen as technology related equipment with the use of equipment, media and means for achieve educational goals or in other words teaching with audio-visual [2].

In this study, the technology used is Google Meet, which is a product and video communication service developed by Google. This application is one of the 2 applications which is a new version of the previous versions (Google Hangouts and Google Chat). This service is launched as a video-conferencing application that can invite up to 30 participants and even hundreds of participants with features that must be paid for. The existence of this application can help carry out activities from home online so that people can still meet face to face even from home.

In this study, Google Meet was used as a media for learning vocal techniques because nowadays face-to-face learning seems difficult. This application was chosen as a vocal technique learning media because it has several advantages as the following: (1) it can be downloaded for free; (2) the quota usage is less than other similar applications; (3) it has a longer duration than other applications; (4) it can be subscribed at a more affordable cost; (5) it is easy to use or operate (unlike other applications that require several complicated and timeconsuming stages); and (6) the email is already integrated with Gmail [3].

With the Google Meet application as a vocal technique learning media, learning materials could still be conveyed properly and effectively. These vocal techniques include breathing, diction, and articulation. This vocal technique learning activity was carried out with grade 10 students from SMA Negeri 1 Cilaku-Cianjur with a total of 5 students. All learning activities through the Google Meet application were carried out from home. 


\section{METHODS}

The method used in conducting this study was Classroom Action Research [4]. Classroom Action Research is defined as action research conducted by a teacher who acts at the same time as a researcher in the class or together with other people (collaboration) by designing, implementing, and reflecting on collaborative and participatory actions that aim to improve or enhance the quality of the learning process in the classroom through a particular treatment in one or more cycles.

The name of the method contains three words. The first is "research" which refers to an activity of observing an object by using certain methods and methodological rules to obtain data or information that is useful in improving the quality of something that is of interest and importance to researchers. The second word is "action" that refers to an object of activity that is deliberately carried out for a specific purpose. In this study, there are several series of activity cycles given to students. The last word is "class". In this case, the class is not tied to the notion of a classroom. In a more specific sense, class means a group of students who at the same time receive the same lesson from the same teacher.

By combining these three words, it can be concluded that Classroom Action Research is an examination of learning activities in the form of an action that is deliberately carried out in a class together. These actions are given by the teacher or with directions from the teacher and then are carried out by students.

The reason for using Kemmis and McTaggart's model was because the stages in the action are simple so that they were easily understood by the researchers. Another consideration from using this model was because the problems faced requiring resolution through the CAR method [5].

The class referred to in this method is a learning activity accommodated by the Google Meet application media so that students and teachers remained at home. Students who took part in the learning were grade 10 students at SMA Negeri 1 Cilaku - Cianjur.

\section{RESULTS AND DISCUSSION}

The study was conducted on 5 students in grade 10 at SMA Negeri 1 Cilaku-Cianjur, West Java, Indonesia in the academic year 2020/2021. This learning process was carried out through the Google Meet application online at home because it was not possible if done directly considering the Covid-19 pandemic. This research was conducted in two cycles where after 2 cycles the indicators of success had been achieved. Vocal technique learning materials included breathing techniques, diction, and articulation. Vocal art is an attempt to express or singing the song so that it can be enjoyed by other people as well as possible [6]. Vocal is the main tool in fixing experience and enrichment of music as well as the most original avenues for express feelings [7]. The song used in this vocal technique learning is entitled "Syukur/Gratitude" by Husein Mutahar.
All types of video conferencing applications do not have certain features that help in learning vocal techniques, but there are several advantages of why Google Meet was chosen.

In addition to free use, Google Meet has a duration of 60 minutes so learning vocal techniques can take longer because it requires a step-by-step process such as warming up and discussion of each phrase in the vocal learning.

Another excellent thing is that the use of quota data is more efficient than other applications--it can even be more economical if there are fewer participants. Vocal technique learning will be more effective individually since students' abilities vary. So, it is better when learning is done with fewer participants. The steps in starting a video conference are very easy and different from most other applications that are complicated and time-consuming. These stages are basically intended to maintain privacy and security, however, because this conference is a learning activity, strict privacy is not needed. Besides, Google Meet is already integrated with Gmail while other applications like Zoom and Microsoft Teams are only integrated with Outlook. In fact, most students today use the email that is integrated with Gmail. If someone has a paid subscription, Google Meet will be the cheapest at USD6 (IDR 94,446)/ month while the competing application, Zoom, costs US15 (IDR 236,115)/ month source by medcom.id.

In terms of overall features, description, usage, and customization needs, Google Meet is more suitable for individual learning or with just a few students while Zoom is more suitable for large-scale meetings and Microsoft Teams for business.

In the pre-cycle stage, students had some problems when singing the song "Syukur/Gratitude" in terms of breathing techniques, diction, and articulation of certain phrases or words so that their performance was not optimal.

\section{A. Cycle 1}

At the stage of the cycle I, the breathing technique was still incorrect and not regular on some phrases. The first phrase that was wrong in the breathing technique was in the sentence "hati ikhlasku penuh/ my heart is fully sincere". In that phrase, the students took a breath so that it became "ikhlasku - penuh" and it sounded like a rush. The second problem was in the phrase "akan karuniamu/ to your blessings". In this sentence, the students also took a breath so that it became "karuni-amu" which changed the lyric meaning. The third problem was in the phrase "kehadiratmu tuhan/ to your presence". In this sentence, the students did not take a breath after finishing on the word "kehadiratmu" so that the word "Tuhan" was not long enough because they already sighed.

In the diction technique, there were errors in choosing words. The first phrase that was wrong in this technique was in the initial sentence of the song Syukur; "dari yakin ku teguh". In that sentence, the students cut the word "te-guh" so it did not sound beautiful. The second phrase was in the sentence "tanah air pusaka". In that sentence, the students cut the word "pu- 
saka" so that it did not sound beautiful and even changed the meaning.

In the articulation technique, students also did not really open their mouths. The pronunciation of some words was also less clear in almost all words so that what was conveyed was not clear enough.

\section{B. Cycle 2}

In the second cycle stage, the students' ability in breathing techniques was better. The students were able to catch their breath well. The first example was in the sentence "hati ikhlasku penuh" where students did not sigh in the middle. Then, in the sentence "akan karuniamu" they did not take a breath in the middle of the word "karuniamu". The last one was in the sentence "kehadiratmu tuhan" where the students were able to place the time to breathe well so that the word "Tuhan" or the end of the word sounded longer than before.

In the diction technique, students were able to pronounce the words well. In the word "teguh", for example, they no longer cut the word. Then, in the word "pusaka", they did not pause the word so that both sounded beautiful and full of meaning. In the articulation techniques, students sang the work clearly so that the message in the song was conveyed well.

\section{CONCLUSION}

The best learning process is face-to-face or in person. However, the Covid-19 pandemic situation forces the teachers to do online learning to reduce the spread of the virus. The Google Meet application is a fairly effective alternative that can be used so that vocal learning can continue. The results showed that the indicators of success had been reached in the second cycle. This study showed that the Google Meet application could display the vocal technique learning process very well so that the material could be conveyed and understood well by students.

This article was expected to be useful as a solution to problems in learning activities, especially learning vocal techniques during the Covid-19 pandemic.

\section{REFERENCES}

[1] Center for Tropical Medicine, Buku Saku Desa Tangguh Covid-19. Yogyakarta: Universitas Gadjah Mada, 2020, pp. 6.

[2] M. Ramli, Media dan Teknologi Pembelajaran. Banjarmasin: Antasari Press Banjarmasin, 2020, pp. 19.

[3] Direktorat Pengembangan Pendidikan ITB, Google Meet: Panduan Mengelola Web Confernce. Edunex, 2020, pp. 2.

[4] Kusnandar, Langkah-langkah Mudah Penelitian Tindakan Kelas Sebagai Pengembangan Potensi Guru. Depok: Rajagrafindo Persada, 2008, pp. 44.

[5] Stephen Kemmis-Robin McTaggart, The Action Research Planner. Springer, 2014.

[6] Savitri Martha Ratnaningtyas, "Pembelajaran Vokal Pada Paduan Suara Vocalista Angels di Klaten” Yogyakarta, 2005.

[7] Sipayung Evarita Meilinda, "Perbedaan Prestasi Belajar Bernyanyi Antara Siswa siswa yang diberi Pembelajaran Solfegio di SMA Stella Duce 1" Yogyakarta, 2007. 